\title{
Bitolterol Mesylate
}

National Cancer Institute

\section{Source}

National Cancer Institute. Bitolterol Mesylate. NCI Thesaurus. Code C65268.

The mesylate salt of bitolterol, a diester sympathomimetic amine with bronchodilator activity. As an ester prodrug, bitolterol is hydrolyzed by esterases to its active metabolite colterol ( $\mathrm{N}$-t-butylarterenol). Colterol selectively binds to and activates beta-2 adrenergic receptors in bronchiolar smooth muscle, thereby causing stimulation of adenyl cyclase, the enzyme that catalyzes the conversion of adenosine triphosphate (ATP) to cyclic-3',5'adenosine monophosphate (CAMP). Increased intracellular CAMP levels cause relaxation of bronchial smooth muscle. This increases air flow and prevents bronchospasms and may eventually lead to an improvement of airway function. 